\title{
Comparison of global 3-D aviation emissions datasets
}

\author{
S. C. Olsen ${ }^{1}$, D. J. Wuebbles ${ }^{1}$, and B. Owen ${ }^{2}$ \\ ${ }^{1}$ Department of Atmospheric Science, University of Illinois Urbana-Champaign, Urbana Il 61801, USA \\ ${ }^{2}$ Dalton Research Institute, Manchester Metropolitan University, John Dalton Building, Chester Street, \\ Manchester M1 5GD, UK
}

Correspondence to: S. C. Olsen (solsen@illinois.edu)

Received: 9 May 2012 - Published in Atmos. Chem. Phys. Discuss.: 10 July 2012

Revised: 6 December 2012 - Accepted: 10 December 2012 - Published: 15 January 2013

\begin{abstract}
Aviation emissions are unique from other transportation emissions, e.g., from road transportation and shipping, in that they occur at higher altitudes as well as at the surface. Aviation emissions of carbon dioxide, soot, and water vapor have direct radiative impacts on the Earth's climate system while emissions of nitrogen oxides $\left(\mathrm{NO}_{\mathrm{x}}\right)$, sulfur oxides, carbon monoxide (CO), and hydrocarbons (HC) impact air quality and climate through their effects on ozone, methane, and clouds. The most accurate estimates of the impact of aviation on air quality and climate utilize threedimensional chemistry-climate models and gridded four dimensional (space and time) aviation emissions datasets. We compare five available aviation emissions datasets currently and historically used to evaluate the impact of aviation on climate and air quality: NASA-Boeing 1992, NASA-Boeing 1999, QUANTIFY 2000, Aero2k 2002, and AEDT 2006 and aviation fuel usage estimates from the International Energy Agency. Roughly $90 \%$ of all aviation emissions are in the Northern Hemisphere and nearly $60 \%$ of all fuelburn and $\mathrm{NO}_{\mathrm{x}}$ emissions occur at cruise altitudes in the Northern Hemisphere. While these datasets were created by independent methods and are thus not strictly suitable for analyzing trends they suggest that commercial aviation fuelburn and $\mathrm{NO}_{\mathrm{x}}$ emissions increased over the last two decades while $\mathrm{HC}$ emissions likely decreased and $\mathrm{CO}$ emissions did not change significantly. The bottom-up estimates compared here are consistently lower than International Energy Agency fuelburn statistics although the gap is significantly smaller in the more recent datasets. Overall the emissions distributions are quite similar for fuelburn and $\mathrm{NO}_{\mathrm{x}}$ with regional peaks over the populated land masses of North America, Europe, and East Asia. For $\mathrm{CO}$ and $\mathrm{HC}$ there are relatively larger differences. There are however some distinct differences in the
\end{abstract}

altitude distribution of emissions in certain regions for the Aero2k dataset.

\section{Introduction}

Aviation contributes greatly to the world's economy. Its total economic impact is estimated to be nearly $8 \%$ of global economic activity and it carries about $40 \%$ of the value of freight (ATAG, 2008). It is an integral part of trade and travel and the industry is expected to grow in the future (IPCC, 1999; Lee et al, 2009; Boeing, 2011; FAA, 2011). However, while aviation enables economic activity, its emissions have adverse impacts on the Earth's air quality and climate. The combustion products from aviation are unique compared to other transportation emissions, e.g., road transportation and ships, in that they are emitted predominantly at cruise altitudes from 8 to $12 \mathrm{~km}$ where there are no other in situ emissions sources except for lightning which is the largest source of $\mathrm{NO}_{\mathrm{x}}$ in the free troposphere $\left(\sim 5 \pm 3 \mathrm{Tg} \mathrm{N} \mathrm{yr}^{-1}\right.$, Schumann and Huntrieser, 2007). While most of these products are emitted in the troposphere some are emitted directly into the lower stratosphere (Gettelman and Baughcum, 1999; IPCC, 1999; Whitt et al., 2011). Aviation emissions of carbon dioxide $\left(\mathrm{CO}_{2}\right)$, soot, and water vapor $\left(\mathrm{H}_{2} \mathrm{O}\right)$ have direct radiative impacts on the climate system while emissions of nitrogen oxides $\left(\mathrm{NO}_{\mathrm{x}}\right)$, sulfur oxides $\left(\mathrm{SO}_{\mathrm{x}}\right)$, carbon monoxide (CO), and hydrocarbons ( $\mathrm{HC}$ ) have indirect radiative impacts through their interactions with complex gaseous and aerosol processes affecting ozone, methane, and clouds. Generally, aviation emissions of $\mathrm{CO}$ and $\mathrm{HC}$ do not significantly affect background atmospheric chemistry; however, even though aviation $\mathrm{NO}_{\mathrm{x}}$ emissions account for a relatively 
small percentage of anthropogenic $\mathrm{NO}_{\mathrm{x}}$ emissions they have a disproportionate impact due to the altitude of the emissions. The ozone production efficiency of cruise level $\mathrm{NO}_{\mathrm{x}}$ emissions is much greater than that of $\mathrm{NO}_{\mathrm{x}}$ emitted at the surface (IPCC, 1999; Gauss et al., 2006; Köhler et al., 2008) and the radiative impact of changes in ozone is greater for perturbations in the upper troposphere than at the surface (e.g., Lacis et al., 1990). While the impact of aircraft emissions (per kg emitted) is larger than that of ground level emissions it is estimated that the climate impact of aviation is still less than half of that from road transportation due to its overall smaller emissions (Skeie et al., 2009).

Due to its long lifetime the emission location of $\mathrm{CO}_{2}$ does not affect its climate impact. In 2005 it was estimated that aviation emissions accounted for nearly $1.6 \%$ of the anthropogenic $\mathrm{CO}_{2}$ radiative forcing (RF) (Lee et al., 2009). The RF due to all aviation emissions was estimated to account for $4.9 \%$ of the total (Lee et al., 2009) and these percentages are expected to increase in the future (IPCC, 1999; Macintosh and Wallace, 2009). Due to the economic importance and possible adverse impacts of aviation, several coordinated efforts and reviews of the impacts have been undertaken (e.g., Brasseur, 1998; IPCC, 1999; AERONOX; ATTICA; QUANTIFY; NASA AEAP) and aviation impacts are addressed in global climate and ozone assessments (e.g., IPCC, 2001, 2007).

Currently the most accurate estimates of the impact of aviation on the Earth's chemistry and climate are obtained from global three-dimensional chemistry-climate models with comprehensive treatments of atmospheric, land, and ocean transport and chemistry processes. Detailed estimates of aviation emissions as a function of space and time are necessary inputs for these models. These aviation emission datasets are typically based on a bottom up approach using detailed estimates of aviation activity and route distribution, the emissions characteristics of aircraft engines, and fuel usage. Over the past several decades aviation emissions datasets have been prepared and made available to the public for use in evaluating current and possible future impacts of aviation on atmospheric chemistry and climate. Given the global importance of aviation and its expected growth in the future it is crucial that the impact of aviation be accurately evaluated. It is thus important to compare emissions and emission distributions of these datasets to determine to what level they are similar or different, whether there have been fundamental changes in the understanding of aviation emission estimates over time and whether there have been any significant changes in the distribution of aviation emissions that could have an impact on atmospheric chemistry and climate.

Here we compare five aviation emission datasets that have been used in chemistry-climate models: NASA Boeing for the years (1) 1992 and (2) 1999 (Baughcum et al., 1996a, b; Mortlock et al., 1998; Sutkus et al., 2001), (3) QUANTIFY (Quantifying the Climate Impact of Global and Eu- ropean Transport Systems project) for the year 2000 (Lee et al., 2005; Owen et al., 2010), (4) Aero2k for the year 2002 (Eyers et al., 2005), and (5) AEDT for the year 2006 (Roof et al., 2007). The Aviation Emissions Inventory Code (AEIC) emissions dataset recently released by the MIT Laboratory for the Environment was not available in time to include in this comparison. Comparison of these databases is not always straightforward since they do not all include emissions from all aviation sectors and often only total emissions are provided so sector by sector comparisons are not possible. For example estimates of military emissions are included only in the NASA-Boeing 1992 and Aero2k datasets. Military emissions are more difficult to estimate than commercial aviation emissions and are more variable from year to year. They are estimated to account for $10-15 \%$ of total emissions (e.g., Mortlock et al., 1998; Waitz et al., 2005).

Evaluating these emission databases is necessary to provide overall context to the emissions databases, to determine whether there are fundamental differences in aviation emissions distributions over time, and perhaps most importantly to provide a footing for comparing the past and future model simulations evaluating the impact of aviation on air quality and climate which make use of one or more of these datasets. Although the datasets are not strictly suitable for emission trend analyses since they were created independently with different models and assumptions it is still informative to examine differences as a function of time.

\section{Aviation emissions datasets}

The International Energy Agency (IEA, www.iea.org) was established in 1974 within the framework of the Organization for Economic Co-operation and Development. The IEA compiles energy use statistics by country and fuel type for many sectors including aviation. IEA aviation fuel usage statistics are based on jet fuel (similar to kerosene) usage where jet fuel is defined as fuel that meets the specifications to be used in aircraft. This specification, however, includes fuel which may be used for airport ground vehicles, engine testing, and other uses (Thompson et al., 1996; Baughcum et al., 1996a; Brassuer et al., 1998). Because of this the IEA data likely represent an upper bound to aviation fuel usage. The IEA fuel data encompass all aviation including military and general aviation and are not disaggregated by aviation sector so the fuel use by sector cannot be evaluated. However the IEA dataset is the most appropriate available data for determining trends in global total aviation fuelburn. We use these data for annual total aviation fuel used from 1990 to 2008 to compare the gridded emissions datasets on a common basis.

All of the datasets examined are three dimensional gridded datasets created for use in three-dimensional chemistryclimate models to evaluate the air quality and climate impacts of aviation. While there are some other available aviation emission datasets, e.g., the Abatement of Nuisances 
Table 1. Global annual commercial fuelburn, emissions, and emissions indices for the NASA-Boeing 1992, NASA-Boeing 1999, QUANTIFY 2000, Aero2k 2002, and AEDT 2006 aviation emissions datasets. Emission indices (EI) are global annual average values.

\begin{tabular}{lccccc}
\hline & NASA-Boeing 1992 & NASA-Boeing 1999 & QUANTIFY 2000 & Aero2k 2002 & AEDT 2006 \\
\hline Fuelburn $\left[10^{11} \mathrm{~kg}\right]$ & 1.10 & 1.36 & 1.52 & 1.54 & 1.88 \\
$\mathrm{NO}_{\mathrm{x}} \mathrm{b}\left[10^{9} \mathrm{~kg}\right]$ & 1.38 & 1.80 & 1.98 & 2.03 & 2.67 \\
$\mathrm{CO}\left[10^{8} \mathrm{~kg}\right]$ & 6.67 & 7.15 & - & 5.00 & 6.76 \\
$\mathrm{HC}{ }^{c}\left[10^{7} \mathrm{~kg}\right]$ & 22.6 & 19.3 & - & 6.24 & 9.76 \\
$\mathrm{NO}_{\mathrm{x}} \mathrm{EI}\left[\mathrm{gNO}_{2} \mathrm{~kg}^{-1}\right]$ & 12.6 & 13.2 & 13.0 & 13.2 & 14.2 \\
$\mathrm{CO} \mathrm{EI}\left[\mathrm{g} \mathrm{kg}^{-1}\right]$ & 6.1 & 5.2 & - & 3.3 & 3.6 \\
$\mathrm{HC} \mathrm{EI}\left[\mathrm{g} \mathrm{kg}^{-1}\right]$ & 2.1 & 1.4 & - & 0.4 & 0.5 \\
\hline
\end{tabular}

a Based on QUANTIFY data before scaling to IEA totals.

b $\mathrm{NO}_{\mathrm{X}}$ reported as $\mathrm{NO}_{2}$.

${ }^{c} \mathrm{HC}$ reported as $\mathrm{CH}_{4}$ emissions.

- The QUANTIFY database does not include CO or HC.

Caused by Air Transport and European Community (ANCAT/EC) and Deutsches Zentrum für Luft- und Raumfahrt (DLR) (Gardener et al., 1997; IPCC, 1999) here we focus on several inventories for the 1990s and early 2000s. These inventories use a "bottom-up" approach in which the emissions are calculated based on: (1) a combination of one or more aircraft movement databases to obtain global air traffic coverage and (2) a database of engine and aircraft characteristics from which aircraft performance and emissions along a flight path can be calculated. The aircraft movement databases are generally based on a combination of flight operation data, flight plans, radar tracking from the United States Federal Aviation Administration (FAA) and/or the European Organization for the Safety of Air Navigation (EUROCONTROL), Official Aviation Guide (OAG) data, and idealized great circle routes. The makeup of the aircraft/engine database varies from database to database and often lumps the many different aircraft/engine combinations into representative groups. From these data combinations along with payload estimates, detailed calculations of fuel burn and emissions are made with an aircraft performance model. Once these data have been compiled, estimates of fuel burned and emissions are calculated for each route and then gridded on a three-dimensional latitude-longitude-altitude grid. All of the gridded aviation datasets examined here are provided on a $1^{\circ}$ latitude $\times 1^{\circ}$ longitude horizontal grid. The vertical grids are expressed as pressure altitude based on the US standard atmosphere.

In each of these datasets various assumptions are made to make up for unknown data or flight characteristics. Taken together these assumptions could tend to underestimate the actual fuel burn. For example, in areas where aircraft cannot be accurately tracked by radar, great circle (minimum distance) flight paths are often assumed, air traffic control delays which increase flight time may not be included, and flight rerouting due to weather conditions or congestion may not be included. Additionally the effects of headwinds and tailwinds are not accounted for. Overall, most of these uncertainties would tend to underestimate the actual fuel burn. The degree to which each of these uncertainties are accounted for depends on the dataset. Based on radar data from North America and Europe it has been estimated that OAG great circle routes underestimate actual aviation operations by $10-15 \%$.

The Boeing Company and NASA produced aviation emissions estimates for scheduled air traffic for the years 1976, 1984, 1992, 1999, and 2015 (Baughcum et al., 1996a, b; Sutkus et al., 2001). Aviation emissions estimates for unscheduled air traffic (military, general aviation, and charter) were produced for 1992 and 2015 (Mortlock et al., 1998). General aviation is defined as all civil aviation operations other than scheduled air services and non-scheduled air transport operations for remuneration or hire. Here we use the 1992 dataset which includes emissions estimates for scheduled, charter, and general aviation and a dataset for 1999 which includes scheduled air traffic from Sutkus et al. (2001) and estimates of other non-military emissions (general aviation and charter) interpolated from the corresponding 1992 and 2015 emissions datasets. These datasets have been used in many modeling studies and are still currently in use (e.g., Emmons et al., 2010). These datasets include fuelburn and emissions of $\mathrm{NO}_{\mathrm{x}}, \mathrm{CO}$, and $\mathrm{HC}$ at a $1 \mathrm{~km}$ vertical resolution. Military emissions estimates for 1992 were produced by the McDonnell Douglas Corporation (Mortlock et al., 1998) which merged with the Boeing Company in 1997. The military emissions estimates are provided at an annual temporal resolution while the other emissions are provided as monthly means. In the following analyses commercial aviation includes all emissions except military and general aviation emissions.

Aviation emissions databases for the years 2000, 2025, 2050, and 2100 were produced within QUANTIFY, an Integrated Project funded through the EU-Framework Programme 7. They were developed with the Future Aviation Scenario Tool (FAST) modeling system and the Project Interactive Analysis and Optimization (PIANO) aircraft performance model assuming great circle flight paths between cities using the OAG for scheduled aircraft movements (Lee 
et al., 2005). This dataset contains fuelburn and emissions of $\mathrm{NO}_{\mathrm{x}}, \mathrm{CO}_{2}$, and particulates at $610 \mathrm{~m}$ vertical resolution. The $610 \mathrm{~m}$ vertical resolution was chosen because it coincides well with $2000 \mathrm{ft}$ flightlevels. The released version of the QUANTIFY dataset was scaled to the IEA aviation fuelburn total for 2000. Thus while the QUANTIFY aviation emissions in the distributed dataset do not directly include military or general aviation emissions these are included indirectly through the scaling to the IEA total fuelburn. This scaling introduces some uncertainty into the total dataset since while the total fuelburn and emission totals may be more accurately represented, the underlying areal and temporal distributions and emission ratios of the emissions which were not explicitly included are assumed to be the same as those in the dataset. For example, while the military emissions totals are included with this method their distribution, emissions ratios, and fuel burn rate are assumed to be the same as commercial emissions. Thus the emissions are scaled based on the scheduled air traffic distribution. In this comparison we use the unscaled emissions data and thus are just evaluating the commercial aviation emissions.

The EC 5th Framework Programme project AERO2k has developed aviation emissions datasets for 2002 and 2025 for civil and military aviation (Eyers et al., 2005). The civil aviation gridded data consist of fuel-used, $\mathrm{NO}_{\mathrm{x}}, \mathrm{H}_{2} \mathrm{O}, \mathrm{CO}_{2}, \mathrm{CO}$, hydrocarbon, particulate (mass and number) emissions, and distance flown in each grid cell. These data are provided monthly on a $500 \mathrm{ft}$ altitude grid. The military data is provided on a $1000 \mathrm{ft}$ altitude grid at annual temporal resolution. General aviation emissions are not included. For civil aviation, the aircraft movement database is based on radar tracked flight data covering North America and Europe. Data for other parts of the world were taken from the Back aviation commercial database (Back, 2002) with flight trajectories based on great circle routes between waypoints. Fuel burn and emissions are calculated based on the PIANO aircraft performance tool using 40 representative aircraft types.

The Aviation Environmental Design Tool (AEDT) (Roof et al., 2007) was used to produce a gridded aviation emissions database for the year 2006. This data was created at the individual flight level as described in Wilkerson et al. (2010). These data were provided by the Volpe National Transportation Systems Center. The emission module of AEDT is derived from that developed for the System for assessing Aviation's Global Emissions (SAGE) (e.g., Kim et al., 2005a, b, c, 2007; Lee et al., 2005) and an updated fuel consumption performance model (Senzig et al., 2009). AEDT relies on realworld radar data where available for aircraft movement in North America and Europe which account for $70-80 \%$ of global operations and the OAG for the remaining areas. This dataset includes fuelburn as well as emissions of $\mathrm{NO}_{\mathrm{x}}, \mathrm{CO}$, $\mathrm{HC}, \mathrm{SO}_{\mathrm{x}}$, and particulates. These data are provided at a $500 \mathrm{ft}$ vertical resolution at an hourly temporal resolution. Military and general aviation emissions are not included in the AEDT dataset. A detailed description of the AEDT dataset is given in Wilkerson et al. (2010).

\section{Results and discussion}

\subsection{Global characteristics}

The aviation industry and hence fuelburn and emissions are dependent on the global economy and other outside influences affecting air travel. IEA reported aviation fuelburn has increased by $50 \%$ from $1.6 \times 10^{11} \mathrm{~kg}$ in 1990 to $2.4 \times 10^{11} \mathrm{~kg}$ in 2008 (Fig. 1). The average rate of increase was $\sim 2.3 \% \mathrm{yr}^{-1}$ which however varied over this time. From 2000 to 2002 there was relatively little change in the fuelburn and the fuelburn in 1991 and 1992 was actually lower than in 1990. The majority of the increase took place from 1992 to 2000 when the average rate of increase was $\sim 4 \%$ per year and then from 2003 to 2006 when it increased by an average of $\sim 3.7 \%$ per year. This trend is consistent with a roughly steady year to year increase in air travel interrupted by outside influences adversely affecting commercial air travel, for example, the Persian Gulf War in the early 1990s and the 11 September terrorist attacks and severe acute respiratory syndrome (SARS) outbreak in the early 2000s. Over this time the emissions datasets also show a general increase; however, the bottom up datasets are systematically lower than the IEA totals (Fig. 1). The dataset total fuelburn is less than IEA fuelburn by from $20 \%$ (AEDT) to $12 \%$ (NASA-Boeing 1992). For commercial fuelburn only (not military or general aviation) the datasets are $28 \%$ (NASA-Boeing 1992), $33 \%$ (NASA-Boeing 1999), $29 \%$ (QUANTIFY before scaling to IEA 2000), $26 \%$ (Aero2k), and 20\% (AEDT) lower than IEA total fuelburn for the corresponding year (Fig. 1). In this comparison there is considerable variability in the datasets relative to the IEA totals. In the datasets which explicitly include military fuelburn it accounts for $18 \%\left(2.6 \times 10^{10} \mathrm{~kg}\right.$, NASA-Boeing 1992) and $11 \%\left(2.0 \times 10^{10} \mathrm{~kg}\right.$, Aero2k) of the total fuelburn while general aviation accounts for $\sim 2.6 \%$ of total fuelburn $\left(3.7 \times 10^{9} \mathrm{~kg}\right.$ in the NASA-Boeing 1992 dataset).

The commercial fuelburn in the gridded datasets increased by $71 \%$ (AEDT 2006 - NASA-Boeing 1992). This change corresponds to emissions changes of $2.5 \times 10^{11} \mathrm{~kg} \mathrm{CO}$, $1.0 \times 10^{11} \mathrm{~kg} \mathrm{H}_{2} \mathrm{O}$, and $4.7 \times 10^{10} \mathrm{~kg} \mathrm{SO}_{2}$ assuming con-

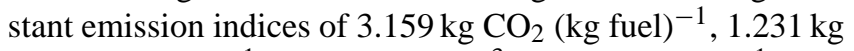
$\mathrm{H}_{2} \mathrm{O}$ (kg fuel) $)^{-1}$, and $0.6 \times 10^{-3} \mathrm{~kg} \mathrm{~S}$ (kg fuel) ${ }^{-1}$ (Table 2). Global commercial $\mathrm{NO}_{\mathrm{x}}$ emissions are also greater in the later datasets, e.g., $1.38 \mathrm{Tg} \mathrm{NO}_{2}$ in the NASA-Boeing 1992 dataset and $2.67 \mathrm{Tg} \mathrm{NO}_{2}$ in the AEDT 2006 dataset as are global annual average $\mathrm{NO}_{\mathrm{x}}$ emissions indices (Fig. 2),

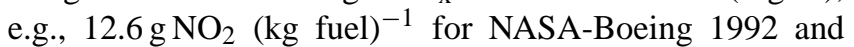

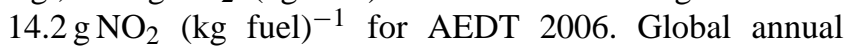
HC emissions in the Aero2k (2002) and AEDT (2006) datasets are lower than in the 1992 and 1999 NASA-Boeing 
Table 2. Derived global annual emissions of $\mathrm{CO}_{2}, \mathrm{H}_{2} \mathrm{O}$, and $\mathrm{SO}_{2}$ for the NASA-Boeing 1992, NASA-Boeing 1999, QUANTIFY 2000, Aero2k 2002, and AEDT 2006 aviation emissions datasets.

\begin{tabular}{lccccc}
\hline & NASA-Boeing 1992 & NASA-Boeing 1999 & QUANTIFY 2000 & Aero2k 2002 & AEDT 2006 \\
\hline $\mathrm{CO}_{2}{ }^{\mathrm{b}}\left[10^{11} \mathrm{~kg}\right]$ & 3.47 & 4.30 & 4.80 & 4.86 & 5.94 \\
$\mathrm{H}_{2} \mathrm{O}^{\mathrm{c}}\left[10^{11} \mathrm{~kg}\right]$ & 1.35 & 1.67 & 1.87 & 1.90 & 2.32 \\
$\mathrm{SO}_{2}-\mathrm{S}^{\mathrm{d}}\left[10^{7} \mathrm{~kg}\right]$ & 6.59 & 8.17 & 9.12 & 9.24 & 11.3
\end{tabular}

a Based on QUANTIFY data before scaling to IEA totals.

b $\mathrm{CO}_{2}$ calculated as $3.159 *$ fuelburn $\left(\mathrm{EI} \mathrm{CO}_{2}=3.159 \mathrm{~kg} \mathrm{~kg}^{-1}\right)$.

${ }^{\mathrm{c}} \mathrm{H}_{2} \mathrm{O}$ calculated as $1.231 *$ fuelburn $\left(\mathrm{EI} \mathrm{H}_{2} \mathrm{O}=1.231 \mathrm{~kg} \mathrm{~kg}^{-1}\right.$ ).

${ }^{\mathrm{d}} \mathrm{SO}_{2}-\mathrm{S}$ calculated as $0.0006 *$ fuelburn $\left(\mathrm{EI} \mathrm{S}=0.6 \times 10^{-3} \mathrm{~kg} \mathrm{~kg}^{-1}\right.$ ).

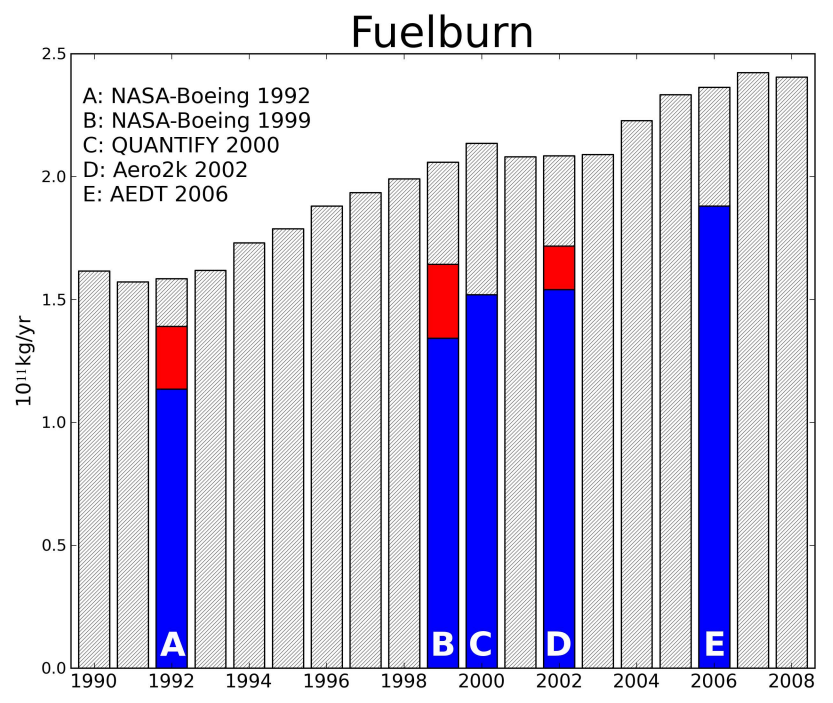

Fig. 1. Aviation fuelburn from the International Energy Agency (hashed bars) overlayed with emissions from NASA-Boeing 1992 and 1999, QUANTIFY 2000, Aero2k 2002, and AEDT 2006 gridded datasets (red $=$ military when available, blue $=$ non-military).

emissions datasets despite the increase in fuelburn over this period. Indeed, the NASA-Boeing (1992 and 1999) HC emissions estimates are approximately three times the Aero2k (2002) and AEDT (2006) estimates. This combined with the increases in fuelburn result in lower average $\mathrm{HC}$ emission ratios (Fig. 2). The Aero2k 2002 dataset has the lowest CO and $\mathrm{HC}$ emissions ratios (Fig. 2).

\subsection{Areal and temporal characteristics of emissions distributions}

In general, aviation emissions intensity is greatest in the northern mid-latitudes (Fig. 3) at cruise altitudes (8-12 km) and near ground level in the landing and take off (LTO) region with relatively smaller emissions intensity in the middle altitudes (Fig. 4). The highest intensity of emissions is over the United States, Europe, and Far East regions (Fig. 3). The areal distributions are quite similar between the datasets with only subtle differences. The general background of emis-
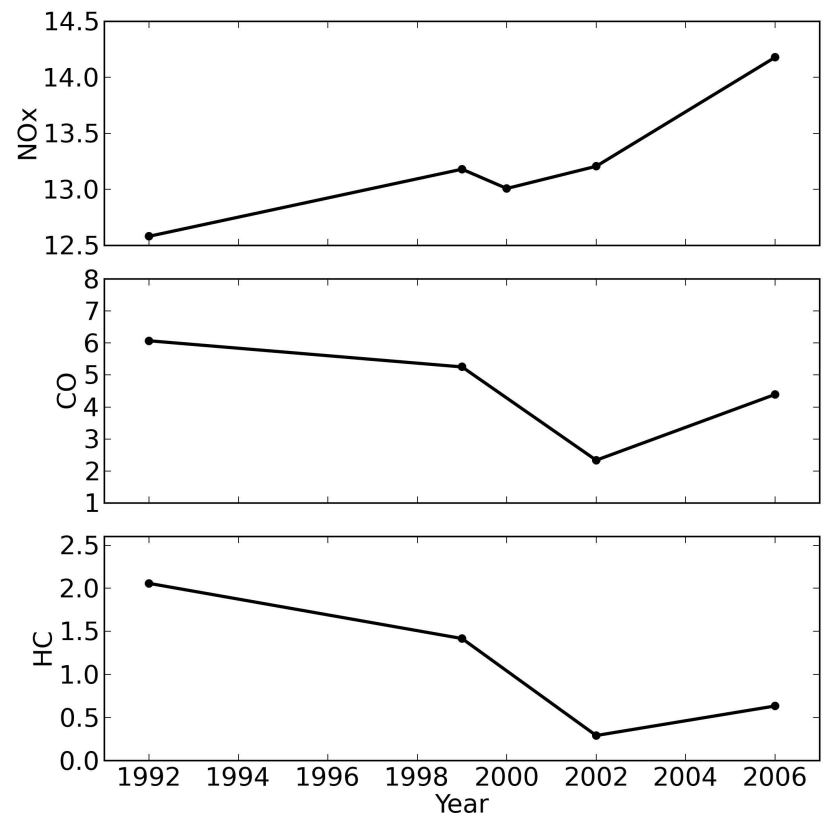

Fig. 2. Global annual average emissions ratios of $\mathrm{NO}_{\mathrm{x}}, \mathrm{CO}$, and $\mathrm{HC}\left[\mathrm{g} \mathrm{kg}^{-1}\right]$ for the NASA-Boeing 1992, NASA-Boeing 1999, QUANTIFY 2000, Aero2k 2002, and AEDT 2006 aviation emissions datasets. QUANTIFY 2000 did not report CO and HC emissions.

sions covers a larger part of the globe in the more recent datasets, for example the in the AEDT 2006 dataset the emissions cover the entire Northern Hemisphere with the exception of very small regions just to the north of Russia while in the NASA-Boeing datasets substantial regions of the Northern Hemisphere have no emissions, e.g., parts of the Pacific Ocean and the high northern latitudes (Fig. 3) with the other datasets falling in between. Also, the Atlantic flight corridor is more localized in the NASA-Boeing 1992 and 1999 and QUANTIFY 2000 datasets than in the Aero2k and AEDT 2006 datasets and the AEDT 2006 dataset has relatively more emissions in East Asia than the other datasets.

The latitudinal distribution of fuelburn is quite similar for all of the datasets (Fig. 3) with virtually no emissions south of $45^{\circ} \mathrm{S}$ latitude, relatively flat between $40^{\circ} \mathrm{S}$ and the equator, 

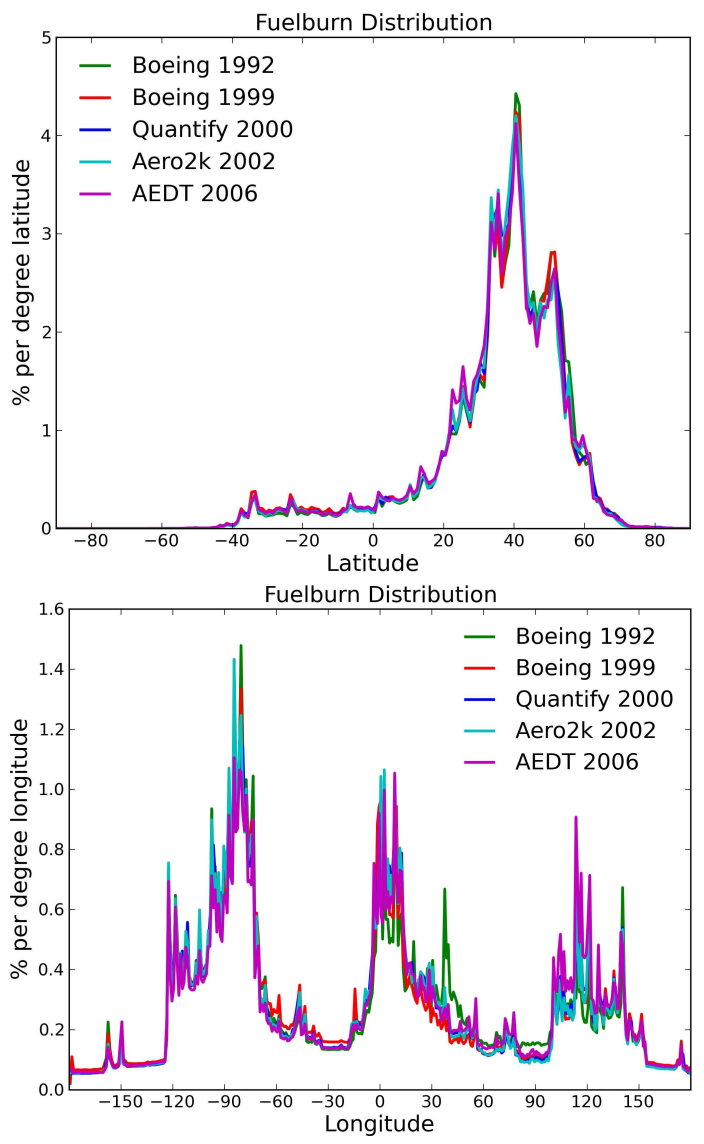

Fig. 3. Annual latitudinal (top) and longitudinal (bottom) commercial fuelburn distribution for the NASA-Boeing 1992 and 1999, QUANTIFY 2000, Aero2k 2002, and AEDT 2006 datasets.

and building to a strong peak in the northern mid-latitudes. There are slightly more emissions around $25^{\circ} \mathrm{N}$ in the AEDT dataset at the expense of emissions around $45^{\circ} \mathrm{N}$ but overall the datasets are remarkably similar. The $\mathrm{NO}_{\mathrm{x}}$ latitudinal distributions (not shown) are similar to the fuelburn. The $\mathrm{CO}$ and $\mathrm{HC}$ distributions show more variability but are still quite similar (also not shown). The longitudinal fuelburn distributions are also quite similar with peaks over the longitudes of the populated land masses. The largest peak $(\sim 1-1.4 \%$ per degree longitude) is from $-120^{\circ}$ to $-70^{\circ}$ corresponding to North America. Peaks around $0^{\circ}(\sim 0.6-1 \%$ per degree longitude) correspond to European longitudes and $100^{\circ}$ to $140^{\circ}(0.2-0.8 \%$ per degree longitude) correspond to East Asian longitudes. While they are mostly quite similar there are some differences. The NASA-Boeing 1992 dataset shows a small peak in fuelburn around $40^{\circ}$ longitude which is not shown in the other datasets, it is also slightly lower around $0^{\circ}$ than the other datasets. The AEDT dataset has relatively more emissions over the East Asia longitudes at the expense of emissions in the North America longitudes. As with the latitudinal distributions the longitudinal $\mathrm{NO}_{\mathrm{x}}$ distributions are quite similar to the fuelburn distributions.

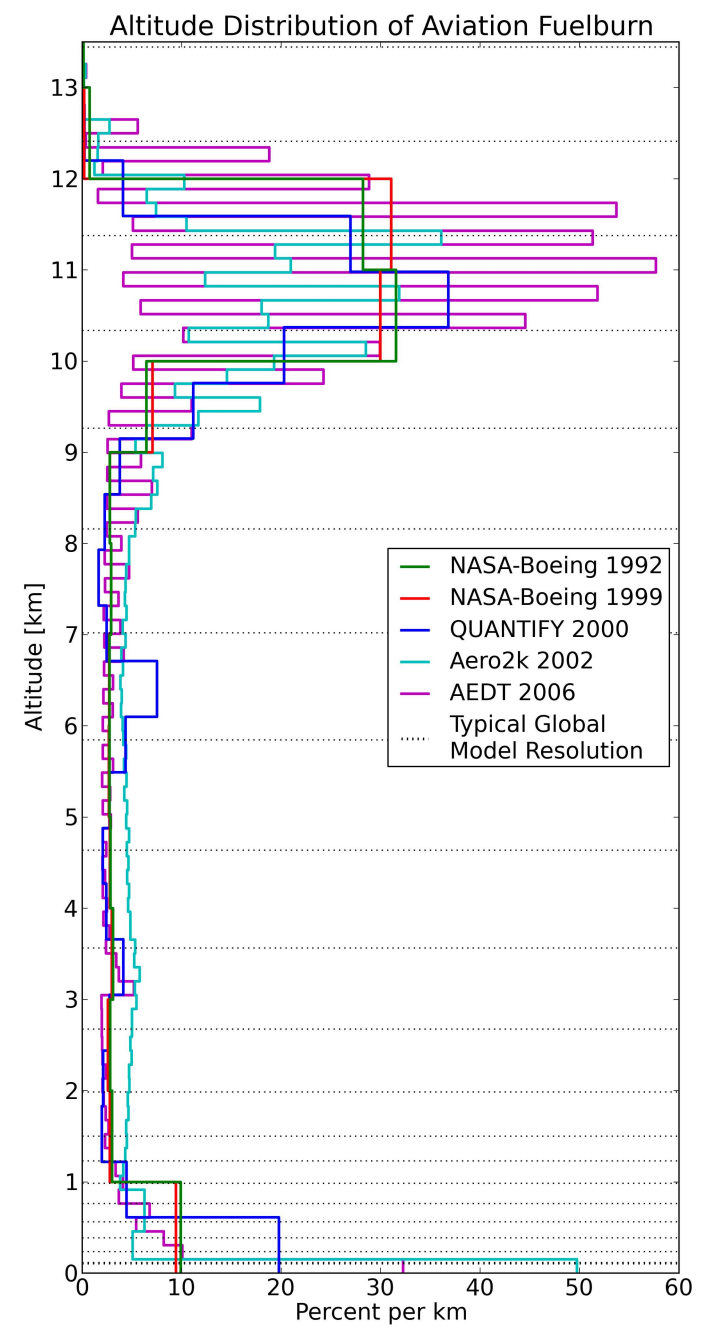

Fig. 4. Annual global vertical distribution of commercial aviation fuelburn for the NASA-Boeing 1992 and 1999, QUANTIFY 2000, Aero2k 2002, and AEDT 2006 datasets. Data are shown versus pressure altitude at their native vertical resolutions. Also shown is the vertical resolution of a typical global 3-dimensional chemistryclimate model (the Community Atmosphere Model (CAM), version 5 with 31 layers).

The increased vertical resolution in the more recent datasets is evident in Fig. 4 with the individual flight levels distinguishable in the Aero2k and AEDT datasets with their $500 \mathrm{ft}$ vertical resolution.

Emission intensities at cruise altitudes range from $\sim 55 \% \mathrm{~km}^{-1}$ for the AEDT dataset down to $\sim 8 \% \mathrm{~km}^{-1}$ also for the AEDT dataset. The extremes in emissions intensity are directly attributable to the aircraft flight levels (which are typically separated by $\sim 1000 \mathrm{ft}$ intervals for safety concerns) and the smaller levels at the higher dataset vertical resolutions. While the Aero2k dataset also has $500 \mathrm{ft}$ vertical resolution it does not reach the same extremes in intensity as the AEDT dataset as it appears not to have the same 
definition between flight levels as in the AEDT dataset. In fact, the Aero2k dataset documentation suggests that above the lowest layer the adjacent data levels be combined when using the data for modeling as the separation of flight levels in the emissions dataset may not accurately reflect the actual aircraft flight paths. Over the mid-altitude region $(1-8 \mathrm{~km})$ all of the datasets have relatively low emissions intensity of $\sim 3 \% \mathrm{~km}^{-1}$, although in the QUANTIFY dataset there is an increase in emissions (up to $\sim 8 \% \mathrm{~km}^{-1}$ ) around $6 \mathrm{~km}$ altitude and the Aero2k dataset is higher throughout the midaltitude region. Near the surface the increased vertical resolution is also evident with higher emissions intensity in the level closest to the ground.

The relationship between the vertical resolution of the datasets and the models used to evaluate the aviation impact on air quality and climate can impact the model simulation results. For example, the same mass of emissions distributed into a larger model grid box will result in a lower concentration than the same emission distributed into a smaller model grid cell. This difference could have implications on the resulting simulated impacts particularly with photochemistry and aerosol and cloud contrail interactions. Near the surface most models have a relatively high vertical resolution (Fig. 4) which would resolve the structure of the LTO emissions in the AEDT and Aero2k datasets resulting in higher emissions into a smaller model grid cell whereas the emissions in the other datasets with relatively coarse vertical resolution would tend to be spread over many model levels. As model resolution increases in the future the resolution of the datasets will gain in importance for the upper troposphere region. There is also work on incorporating plume resolving submodels into global scale models to better represent the sub-grid processes (e.g., Naiman et al., 2010); however, sub-gridscale plume models require detailed chord level emissions which resolve individual flight tracks. This level of detail is not available in gridded emissions data.

Commercial aviation fuelburn and emissions distributions were compared for six regions; global, North America (15$\left.55^{\circ} \mathrm{N}, 125-60^{\circ} \mathrm{W}\right)$, Europe $\left(25-65^{\circ} \mathrm{N}, 10^{\circ} \mathrm{W}-50^{\circ} \mathrm{E}\right)$, East Asia $\left(10^{\circ} \mathrm{S}-45^{\circ} \mathrm{N}, 60-150^{\circ} \mathrm{E}\right)$, the Pacific Flight Corridor $\left(35-65^{\circ} \mathrm{N}, 140^{\circ} \mathrm{E}-120^{\circ} \mathrm{W}\right)$, and the Atlantic Flight Corridor $\left(40-63^{\circ} \mathrm{N}, 70-5^{\circ} \mathrm{W}\right)$ (Fig. 5). The distribution of fuelburn and $\mathrm{NO}_{\mathrm{x}}$ emissions between the regions is fairly similar between the datasets (Figs. 6 and 7). Over $90 \%$ of both occur in the Northern Hemisphere, roughly $8 \%$ of both occur in the Pacific and Atlantic flight corridors, and around $22 \%$ in the Europe region. Approximately $32 \%$ occur in the North America region while about $20 \%$ are in the East Asia region. While the regional percentages are relatively similar for most regions, in the AEDT 2006 database the East Asia region is slightly higher mostly at the expense of the North America region as also shown in the longitudinal distributions. This is consistent with a shift in air traffic patterns with increasing traffic to the East Asia region.

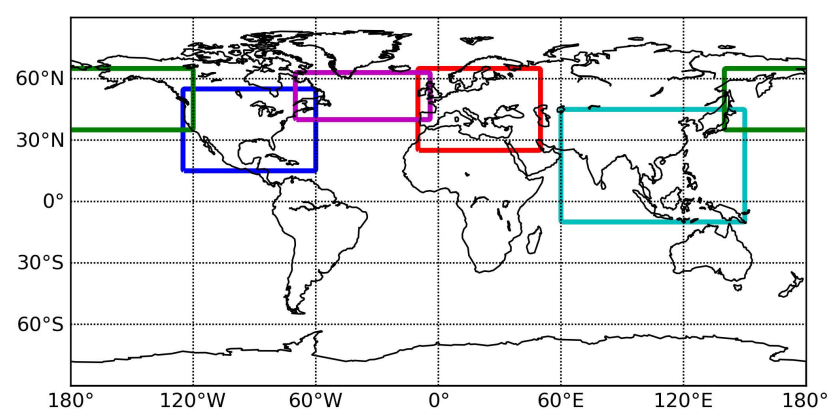

Fig. 5. Regions used for gridded dataset analysis. Green $=$ Pacific Flight Corridor $\left(35-65^{\circ} \mathrm{N}, 140^{\circ} \mathrm{E}-120^{\circ} \mathrm{W}\right)$, Blue = North America (NA) $\left(15-55^{\circ} \mathrm{N}, 125-60^{\circ} \mathrm{W}\right)$, Purple $=$ Atlantic Flight Corridor $\left(40-63^{\circ} \mathrm{N}, 70-5^{\circ} \mathrm{W}\right), \operatorname{Red}=$ Europe $\left(25-65^{\circ} \mathrm{N}, 10^{\circ} \mathrm{W}-50^{\circ} \mathrm{E}\right)$, Cyan $=$ East Asia $\left(10^{\circ} \mathrm{S}-45^{\circ} \mathrm{N}, 60-150^{\circ} \mathrm{E}\right)$.
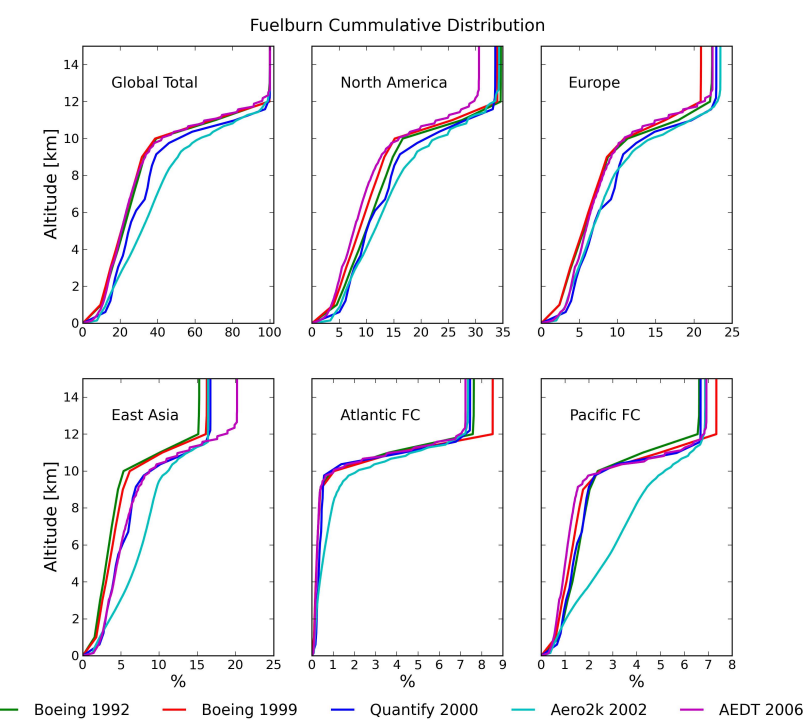

Fig. 6. Annual cumulative commercial fuelburn distributions versus pressure altitude for the NASA-Boeing 1992 and 1999, QUANTIFY 2000, Aero2k 2002, and AEDT 2006 shown for the global total and the regions shown in Fig. 5. Note different scales.

Globally, most fuelburn and $\mathrm{NO}_{\mathrm{x}}$ emissions occur at cruise altitudes (Figs. 6 and 7). In most of the datasets roughly $10 \%$ of fuelburn is in the lowest level, $20 \%$ of fuelburn is in the middle altitudes $(1-8 \mathrm{~km})$, and $70 \%$ is at cruise altitudes. The NASA-Boeing and AEDT global distributions are quite similar. The QUANTIFY dataset has somewhat more LTO emissions likely due to use of the ICAO standard times in mode for the LTO cycle and a bump at around $6 \mathrm{~km}$ due to assumptions regarding altitudinal binning of flights for turboprops (and some other small-medium aircraft) on shorter missions. However, the Aero2k dataset has noticeably more fuelburn in the mid altitude range $(\sim 30 \%)$ and less fuelburn at cruise altitudes $(\sim 55 \%)$. The altitude distribution of fuelburn and $\mathrm{NO}_{\mathrm{x}}$ are quite similar to each other within 


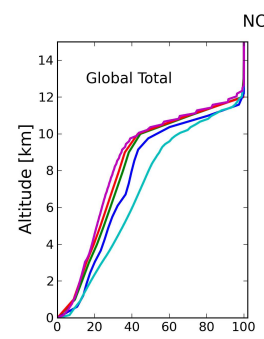

NOx Cummulative Distribution
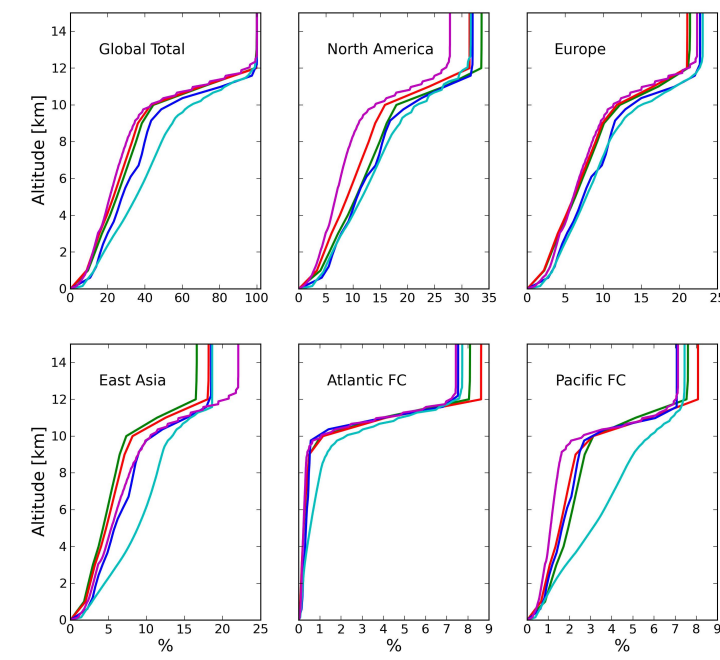

— Boeing 1992 - Boeing 1999

- Quantify 2000

- Aero2k 2002 - AEDT 2006

Fig. 7. Annual cumulative commercial $\mathrm{NO}_{\mathrm{x}}$ emissions distributions versus pressure altitude for the NASA-Boeing 1992 and 1999, QUANTIFY 2000, Aero2k 2002, and AEDT 2006 shown for the global total and the regions shown in Fig. 5. Note different scales.

each region, although compared to fuelburn there is slightly more $\mathrm{NO}_{\mathrm{x}}$ emitted in the mid-altitude region for most of the datasets (Figs. 6 and 7).

Regionally the distributions are the most similar in the Europe region. The Aero2k 2002 dataset stands out from the other datasets particularly in the Pacific flight corridor where it has almost no emissions at cruise altitudes and in the East Asia, Atlantic and Pacific flight corridor regions where it has higher emissions in the mid-altitude range than the other datasets. These regions are responsible for higher mid-altitude emissions in the global in the Aero2k dataset. This is particularly prominent in the Pacific flight corridor region where nearly $75 \%$ of emissions are below $8 \mathrm{~km}$ in the Aero2k dataset while the other datasets have less than $30 \%$ of their emissions below $8 \mathrm{~km}$. This highlights a problem in the Aero2k dataset since in this region most of the flights should be at cruise altitudes since it is mostly over the Pacific Ocean even though the region as defined here contains small parts of Canada and Asia (Fig. 5).

While the altitude distributions of fuelburn and $\mathrm{NO}_{\mathrm{x}}$ are quite similar, the distributions of $\mathrm{CO}$ and $\mathrm{HC}$ emissions are more similar to each other than to either fuelburn or $\mathrm{NO}_{\mathrm{x}}$ emissions (Figs. 8 and 9). As with the global $\mathrm{CO}$ and $\mathrm{HC}$ totals, there is more variability between the datasets for $\mathrm{CO}$ and $\mathrm{HC}$ emissions than for fuelburn or $\mathrm{NO}_{\mathrm{x}}$ emissions, likely a result of the uncertainty involved in their calculation. Relatively more $\mathrm{CO}$ and $\mathrm{HC}$ are emitted in the LTO and midaltitude regions and less at cruise altitudes. Regionally, about $40 \%$ of $\mathrm{CO}$ and $\mathrm{HC}$ emissions occur over the North America regions whereas only about $32 \%$ of fuelburn occurred over this region. Approximately $25 \%, 2.5 \%$, and $5.5 \%$ of
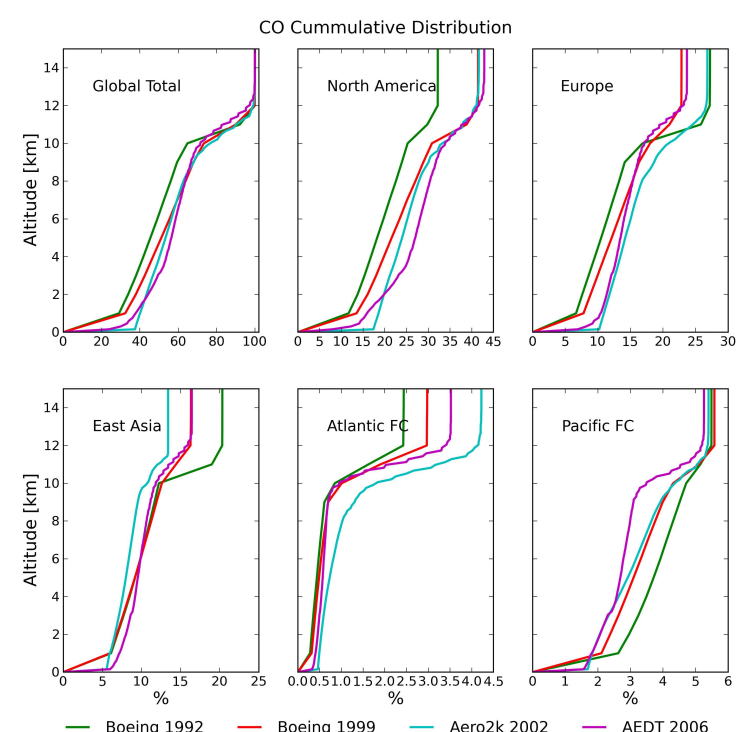

Fig. 8. Annual cumulative commercial CO emissions distributions versus pressure altitude for the NASA-Boeing 1992 and 1999, Aero2k 2002, and AEDT 2006 shown for the global total and the regions shown in Fig. 5. Note different scales.

$\mathrm{CO}$ and $\mathrm{HC}$ emissions occur in the Europe region and the Atlantic and Pacific flight corridors, respectively while these regions account for $22 \%, 8 \%$, and $8 \%$ of fuelburn. While general aviation is a relatively small fraction $(\sim 3 \%)$ of fuelburn and $\mathrm{NO}_{\mathrm{x}}$ emissions, its $\mathrm{CO}$ emissions are nearly the same as for commercial aviation, $6.1 \times 10^{11} \mathrm{~kg}$ and $7.2 \times 10^{11} \mathrm{~kg}$ for the NASA-Boeing 1992 and 1999 datasets respectively. General aviation emissions of $\mathrm{HC}$ are about $16 \%$ and $22 \%$ of the commercial HC emission for the Boeing 1992 and 1999 datasets.

Aviation fuelburn and emissions of $\mathrm{NO}_{\mathrm{x}}, \mathrm{CO}$, and $\mathrm{HC}$ typically peak in Northern Hemisphere summer (July and August). The major features of the seasonal distributions are quite similar among the datasets (Fig. 10). Summertime fuelburn is about $12 \%$ higher than wintertime. The seasonality of fuelburn and $\mathrm{NO}_{\mathrm{x}}$ emissions is somewhat more peaked in the AEDT 2006 and NASA-Boeing 1992 datasets than for the other datasets while the QUANTIFY and Aero2k datasets have a more extended summer peak. The seasonality of $\mathrm{CO}$ and $\mathrm{HC}$ emissions (not shown) is smaller than that of fuelburn but displays the same general features. The diurnal characteristics of fuelburn are also similar in the datasets that report these data (Fig. 11). The AEDT 2006 hourly data show two peaks the largest at around 15:00 UTC $(\sim 4.6 \%$ $\mathrm{h}^{-1}$ ) with a secondary smaller peak at around 2:00 UTC $\left(\sim 4.5 \% \mathrm{~h}^{-1}\right)$ and a minimum near 08:00 UTC $\left(3.5 \% \mathrm{~h}^{-1}\right)$. The Aero2k 2002 6-hourly data displays a peak at 16:00 UTC $\left(\sim 4.9 \% \mathrm{~h}^{-1}\right)$ and a minimum at 09:00 UTC $\left(\sim 3.6 \% \mathrm{~h}^{-1}\right)$ (Fig. 11). When the AEDT 2006 data are binned to the 6h time resolution of the Aero2k 2002 dataset they are quite 


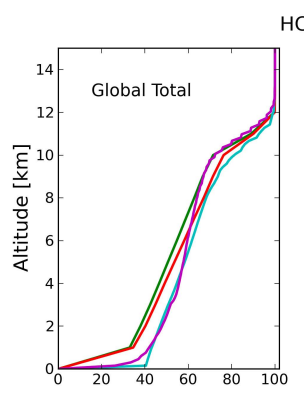

HC Cummulative Distribution
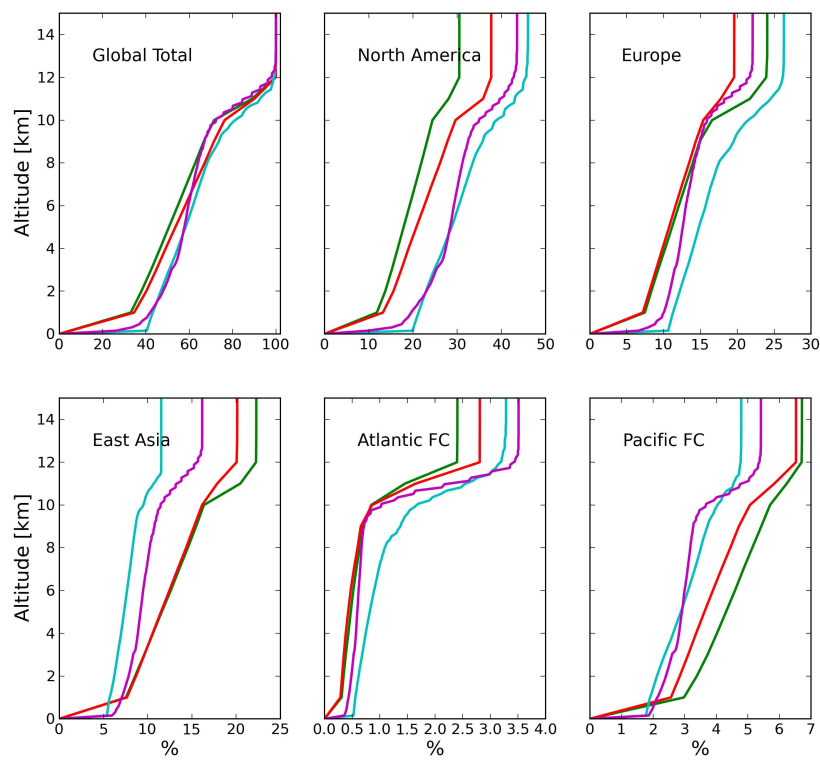

— Boeing 1992 - Boeing 1999 - Aero2k 2002

- AEDT 2006

Fig. 9. Annual cumulative commercial $\mathrm{HC}$ emissions distributions versus pressure altitude for the NASA-Boeing 1992 and 1999, Aero2k 2002, and AEDT 2006 shown for the global total and the regions shown in Fig. 5. Note different scales.

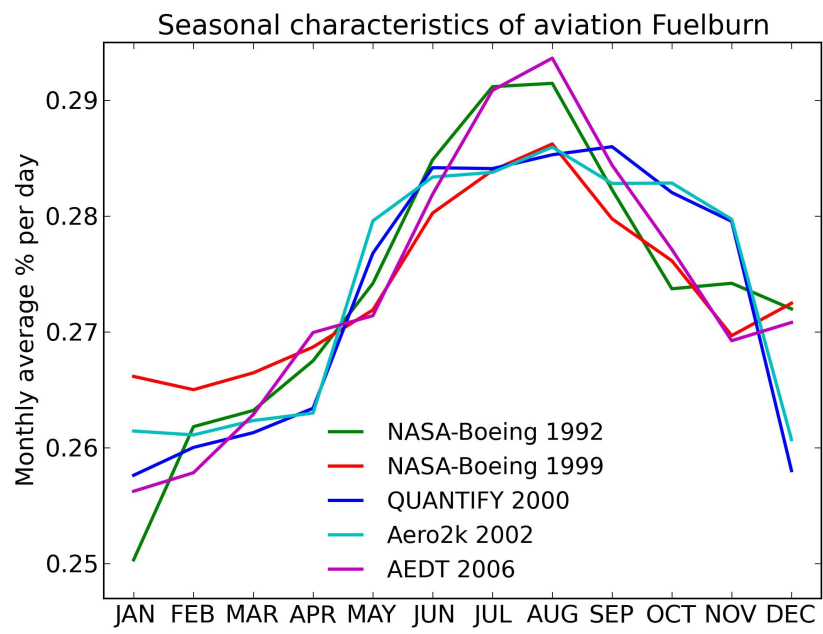

Fig. 10. Monthly fuelburn distribution $\left(\% \mathrm{day}^{-1}\right)$ for the NASABoeing 1992 and 1999, QUANTIFY 2000, Aero2k 2002, and AEDT 2006 aviation emissions datasets.

similar however this may indicate that the 6-h time interval used in the Aero2k data is not sufficient to resolve the secondary peak structure present in the AEDT 2006 data. Converting the AEDT 2006 data to localtime (LT) where $15^{\circ}$ longitude equals $1 \mathrm{~h}$ shows that the maximum fuelburn $\left(\sim 5.5 \% \mathrm{~h}^{-1}\right)$ occurs during between around 10:00 to 04:00 LT (Fig. 11) and the minimum fuelburn $\left(\sim 2.5 \% \mathrm{~h}^{-1}\right)$ occurs between around 22:00 to 06:00 LT.
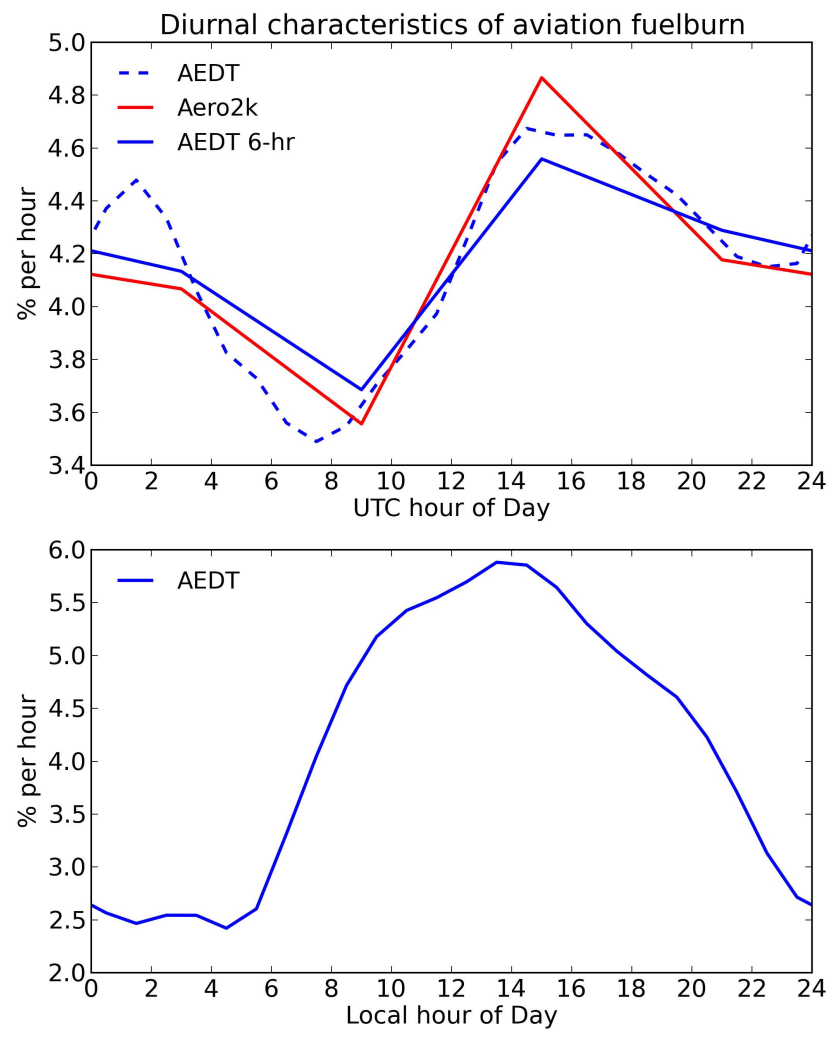

Fig. 11. Diurnal aviation fuelburn distribution $\left[\% \mathrm{~h}^{-1}\right]$ for the Aero2k 2002 and AEDT 2006 datasets in coordinated universal time (UTC) top and localtime bottom. The solid lines in the top figure are $6 \mathrm{~h}$ averages for comparison as the Aero2k data are only available at 6-h resolution and the dotted line is the AEDT 2006 data at its native 1 -h time resolution. The bottom figure is the hourly AEDT 2006 data displayed in localtime.

\subsection{Military emissions distribution}

Military fuelburn and emissions are included separately in the McDonnell-Douglas 1992 and Aero2k 2002 datasets. There are major differences in the areal distribution of military fuelburn between the McDonnel-Douglas and Aero2k military datsets (Fig. 12) even though the latitudinal and longitudinal distributions are quite similar (Fig. 13). The Aero2k emissions are allocated by country while the McDonnellDouglas emissions are allocated in a similar manner to the commercial emissions. The Aero2k 2002 military emissions are distributed relatively uniformly within land regions and/or political boundaries with little or no emissions over oceans. The McDonnell-Douglas military emissions contain more detailed flight routes. Even with these stark differences the major features of the latitudinal distribution of military aviation fuelburn are quite similar between the McDonnellDouglas and Aero2k datasets with emissions peaking in the Northern Hemisphere mid latitudes (Fig. 13). They are also similar to the commercial latitudinal distributions although there is relatively less military fuelburn in the lower latitudes 
Military Fuelburn Areal Distribution

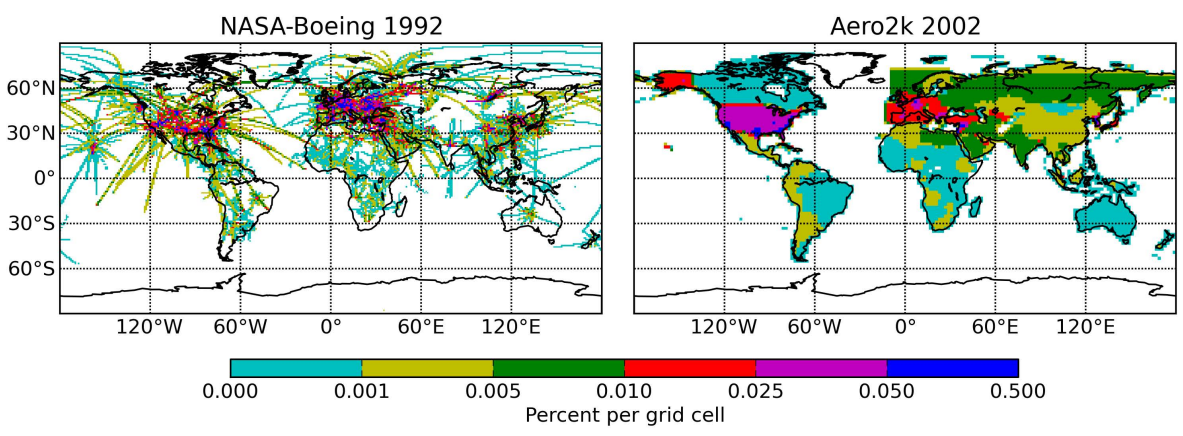

Fig. 12. Annual latitude $\times$ longitude military fuelburn distribution [\% (grid cell) ${ }^{-1}$ ] for the NASA-Boeing 1992 and Aero $2 k 2002$ datasets. Datasets are on $1^{\circ}$ latitude $\times 1^{\circ}$ longitude grids. Note the non-uniform color scale.
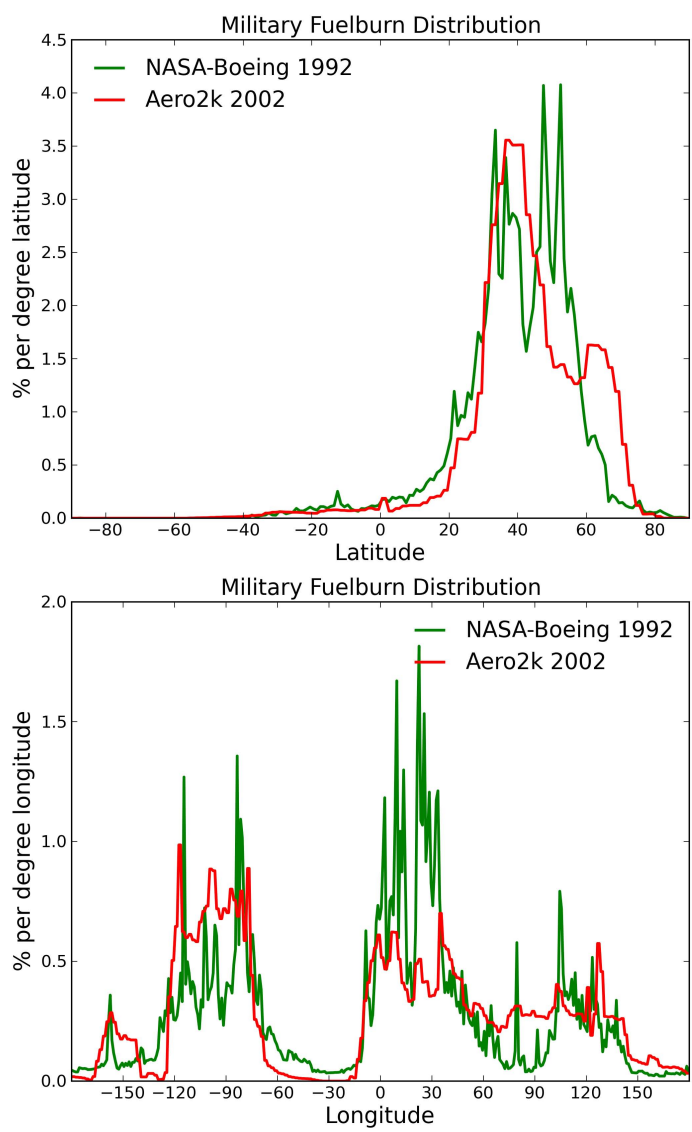

Fig. 13. Annual latitudinal (top) and longitudinal (bottom) military fuelburn distribution for the NASA-Boeing 1992 and Aero2k 2002 datasets.

and more in the higher latitudes, e.g., the sharp peaks in the McDonnell-Douglas datasets around $50^{\circ} \mathrm{N}$ and the bulge in the Aero $2 \mathrm{k} 2002$ dataset around $65^{\circ} \mathrm{N}$. The longitudinal fuelburn distributions (Fig. 13) also show the same general characteristics as the commercial fuelburn distributions although the military datasets have relatively less fuelburn in the $-60^{\circ}$ to $0^{\circ}$ and $150^{\circ}$ to $-160^{\circ}$ longitude range. The McDonnellDouglas dataset has relatively higher fuelburn over $0^{\circ}$ to $30^{\circ}$ longitudes (Europe) at the expense of the $-120^{\circ}$ to $-60^{\circ}$ (North American) longitudes.

In the Aero2k 2002 dataset there is relatively more fuelburn over North America (35\%) than in the McDonnellDouglas dataset $(25 \%)$ and considerably less over Europe ( $23 \%$ versus $40 \%$ ) (Fig. 14). Over these regions the Aero2k 2002 dataset regional total is nearly the same as for commercial fuelburn while the McDonnell-Douglas dataset totals are lower over North America and higher over Europe than the commercial aviation distributions. Both the McDonnellDouglas and Aero2k datasets have a smaller percentage of fuelburn over East Asia and the Atlantic flight corridor than the commercial aviation distributions. In the Pacific flight corridor the Aero2k 2002 percentage is nearly the same for military and commercial while for the McDonnell-Douglas datasets the total is about $2 \%$ less than the commercial. Globally and over most regions the military fuelburn is more spread out in altitude than commercial fuelburn with relatively more emissions in the mid-altitude region and at the higher altitudes. Overall the military "cruise altitude" region is not as well defined as for commercial aviation. The similarity over the Atlantic and Pacific flight corridor regions which contain mostly ocean regions is largely coincidental and is highly sensitive to the choice of region boundaries given the areal distribution in the Aero2k dataset.

\section{Conclusions}

Aviation fuelburn and $\mathrm{NO}_{\mathrm{x}}$ emissions have generally increased over much of the last two decades with commercial aviation responsible for the largest increase. Analysis of the fuelburn and $\mathrm{NO}_{\mathrm{x}}, \mathrm{CO}$, and $\mathrm{HC}$ emissions distributions from five available aviation emissions datasets shows that with the exception of the Aero2k dataset the distributions are similar enough that there has likely not been any significant 

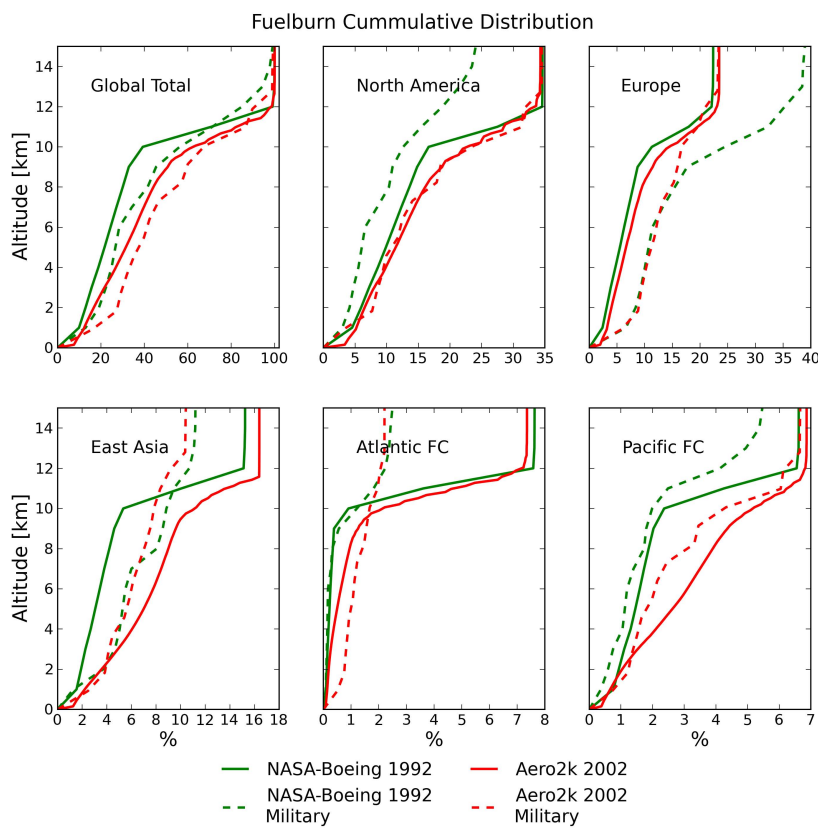

Fig. 14. Annual cumulative commercial (solid lines) and military (dashed lines) fuelburn distributions versus pressure altitude for the NASA-Boeing 1992 and Aero2k 2002 datasets, shown for the global total and the regions shown in Fig. 5. Note the different scales.

change in our knowledge of aviation emissions distributions. The vast majority (roughly $90 \%$ ) of aviation emissions occur in the Northern Hemisphere and nearly $60 \%$ of all fuelburn and $\mathrm{NO}_{\mathrm{x}}$ emissions occur at cruise altitudes in the Northern Hemisphere. Regionally, the largest emissions intensity occurs over the populated land masses in Northern Hemisphere, e.g., North America, Europe, and East Asia. Seasonally, aviation fuelburn is about $12 \%$ greater in July and August than in January and February. While fuelburn and $\mathrm{NO}_{\mathrm{x}}$ emissions are generally quite consistent there are relatively larger differences in the $\mathrm{CO}$ and $\mathrm{HC}$ emissions distributions.

The Aero2k dataset has apparently unrealistic low cruise altitude and high mid-altitude fuelburn and $\mathrm{NO}_{\mathrm{x}}$ emissions over the Pacific flight corridor and East Asia regions. Relative to the other datasets it appears that instead of the emissions occurring at cruise altitudes they are emitted lower in the atmosphere. For this reason its utility assessing the effects of aviation on the atmosphere and climate is questionable. The QUANTIFY dataset has somewhat higher relative emissions in the LTO and around $6 \mathrm{~km}$ in the North America and Europe regions but not to the same degree as in the Aero2k dataset. With the more recent AEDT 2006 dataset and the greater utilization of actual radar tracking instead of OAG routes it appears that the historic underestimate of the IEA fuelburn data in bottom up aviations inventories may be within the uncertainties of the individual aviation sector emissions.
Military aviation emissions which are estimated to account for $\sim 15 \%$ of fuelburn and $\mathrm{NO}_{\mathrm{x}}$ emissions remain highly uncertain. The uncertainties and variability in military emissions may account for the largest source of uncertainty in estimating total aviation emissions, however they are often not included in aviation emissions datasets in part due to the difficulty in quantifying them. For datasets that do not directly include military emissions it may be adequate to scale the dataset emissions up using a suitable factor (perhaps either IEA fuelburn statistics (as in the released QUANTIFY dataset) or assume a fixed military percentage) when total aviation emissions are desired. While military and commercial distributions differ somewhat they are relatively similar in regions with the largest emissions and the uncertainties in this assumption are probably less than the $10-15 \%$ of not including the military emissions at all.

Acknowledgements. The authors would like to thank the Federal Aviation Administration, Aviation Climate Change Research Initiative (ACCRI) for support under Contract \#: 10-C-NE-UI amendment 001 and The Partnership for AiR Transportation Noise and Emissions Reduction (PARTNER). We thank Steve Baughcum for providing the Boeing emissions data, the Aero2k project for the Aero2k data from http://www.cate.mmu.ac.uk/aero2k.asp, and the EU-Framework Programme 6 Integrated Project for the QUANTIFY data www.pa.op.dlr.de/quantify/emissions. The AEDT data was provided by the FAA Office of Environment and Energy through US Department of Transportation Volpe Center. The International Energy Agency data is available from http://www.iea.org/publications/free_new_esc.asp?PUBS_D=2473. The opinions, findings, and conclusions or recommendations expressed in this material are those of the authors and do not necessarily reflect the views of ACCRI, PARTNER, or the FAA. The MIT Laboratory for the Environment AEIC global civil aviation emissions dataset is available from http://lae.mit.edu.

Edited by: P. Jöckel

\section{References}

ATAG, The economic and social benefits of air transport 2008, Air Transportation Action Group, Geneva, Switzerland, available from www.atag.org, 2008.

Back, Back Information Services, Aviation Link: OAG user's guide for software version 2.3, A division of Back Associates, Inc., 2002.

Baughcum, S. L., Henderson, S. C., and Tritz, T. G.: Scheduled Civil Aircraft Emissions Inventories for 1976 and 1984: Database Development and Analysis, NASA CR 4722, 1996 .

Baughcum, S. L., Tritz, T. G., Henderson, S. C., and Pickett, D. C.: Scheduled Civil Aircraft Emissions Inventories for 1992: Database Development and Analysis, NASA CR 4700, 1996 b.

Boeing, Current Market Outlook 2011-2030, Boeing Commercial Airplanes Market Analysis, available from: www.boeing.com/ cmo, 2011.

Brasseur G. P., Cox, R. A., Haulustaine, D., Isaksen I., Lelieveld, J., Lister, D. H., Sausen R., Schumann, U., Wahner, A., and Wiesen, 
P.: European scientific assessment of the atmospheric effects of aircraft emissions, Atmos. Environ., 32, 2329-2418, 1998.

Emmons, L. K., Walters, S., Hess, P. G., Lamarque, J.-F., Pfister, G. G., Fillmore, D., Granier, C., Guenther, A., Kinnison, D., Laepple, T., Orlando, J., Tie, X., Tyndall, G., Wiedinmyer, C., Baughcum, S. L., and Kloster, S.: Description and evaluation of the Model for Ozone and Related chemical Tracers, version 4 (MOZART-4), Geosci. Model Dev., 3, 43-67, doi:10.5194/gmd3-43-2010, 2010.

Eyers, C. J., Addleton, D., Atkinson, K., Broomhead, M. J., Christou, R. A., Elliff, T. E., Falk, R., Gee, I. L., Lee, D. S., Marizy, C., Michot, S., Middel, J., Newton, P., Norman, P., Plohr, M., Raper, D. W., and Stanciou, N.: AERO2k Global Aviation Emissions Inventories for 2002 and 2025, QinetiQ Ltd, Farnborough, Hampshire QINETIQ/04/01113, 2005.

FAA Aerospace Forecast, Fiscal Years 2011-2031, available from: http://www.faa.gov/about/office_org/headquarters_offices/apl/ aviation_forecasts/aerospace_forecasts/2011-2031/media/2011\% 20Forecast\%20Doc.pdf, last access: January 2013.

Gardner, R. M., Adams, K., Cook, T., Deidewig, F., Ernedal, S., Falk, R., Fleuti, E., Herms, E., Johnson, C. E., Lecht, M., Lee, D. S., Leech, M., Lister, D., Masse, B., Metcalfe, M., Newton, P., Schmitt, A., Vandenbergh, C., and Van Drimmelen, R.: The ANCAT/EC global inventory of $\mathrm{NO}_{\mathrm{x}}$ emissions from aircraft, Atmos. Environ, 31, 1751-1766, 1997.

Gauss, M., Isaksen, I. S. A., Lee, D. S., and Søvde, O. A.: Impact of aircraft $\mathrm{NO}_{\mathrm{x}}$ emissions on the atmosphere - tradeoffs to reduce the impact, Atmos. Chem. Phys., 6, 1529-1548, doi:10.5194/acp-6-1529-2006, 2006.

Gettelman, A. and Baughcum, S. L.: Direct deposition of subsonic aircraft emissions into the stratosphere, J. Geophys. Res., 104, 8317-8327, doi:10.1029/1999JD900070, 1999.

ICAO, International Civil Aviation Organization, Forecasts of Scheduled Passenger Traffic: Long-Term Traffic and Aircraft Movement Forecasts, available online at: http://legacy.icao.int/ icao/en/atb/ead/fep/Longterm.htm, 2007.

IPCC: Aviation and the Global Atmosphere. A special report of IPCC working groups I and III, edited by: Penner, J. E., Lister, D. H., Griggs, D. J., Dokken, D. J., and McFarland, M., Special Report of the Intergovernmental Panel on Climate Change, Cambridge University Press, Cambridge, 1999.

IPCC: Climate Change 2001: The Scientific Basis. Contribution of Working Group I to the Third Assessment Report of the Intergovernmental Panel on Climate Change, edited by: Houghton, J. T., Ding, Y., Griggs, D. J., Noguer, M., van der Linden, P. J., Dai, X., Maskell, K., and Johnson, C. A., Cambridge University Press, Cambridge, United Kingdom and New York, NY, USA, 881 pp., 2001.

IPCC: Climate Change 2007: The Physical Science Basis. Contribution of Working Group I to the Fourth Assessment Report of the Intergovernmental Panel on Climate Change, edited by: Solomon, S., Qin, D., and Manning, M., 2007.

Kim, B. Y., Fleming, G. G., Balasubramanian, S., Malwitz, A., Lee, J. J., Ruggiero, J., Waitz, I. A., Klima, K., Locke, M., Holsclaw, C. A., Morales, A., McQueen, E., and Gillette, W.: System for assessing Aviation's Global Emissions (SAGE) Version 1.5: System Revision History, FAA, Ed., Office of Environment and Energy, 21, 2005a.
Kim, B. Y., Fleming, G. G., Balasubramanian, S., Malwitz, A., Lee, J. J., Ruggiero, J., Waitz, I. A., Klima, K., Stouffer, V., Long, D., Kostiuk, P., Locke, M., Holsclaw, C. A., Morales, A., McQueen, E., and Gillette, W.: System for assessing Aviation's Global Emissions (SAGE) Version 1.5: Technical Manual. FAA, Ed., Office of Environment and Energy, 236, 2005 b.

Kim, B. Y., Fleming, G. G., Balasubramanian, S., Malwitz, A., Lee, J. J., Waitz, I. A., Klima, K., Locke, M., Holsclaw, C. A., Morales, A., McQueen, E., and Gillette, W.: System for assessing Aviation's Global Emissions (SAGE) Version 1.5: Global Aviation Emissions Inventories for 2000 through 2004. FAA, Ed., Office of Environment and Energy, 48, 2005c.

Kim, B. Y., Fleming, G. G., Lee, J. J., Waitz, I. A., Clarke, J.-P., Balasubramanian, S., Malwitz, A., Klima, K., Locke, M., Holsclaw, C. A., Maurice, L. Q., and Gupta, M. L.: System for assessing Aviation's Global Emissions (SAGE), Part 1: Model description and inventory results, Transport. Res. Part D: Transportation and Environment, 12D, 325-346, 2007.

Köhler, M. O., Rädel, G., Dessens, O., Shine, K. P., Rogers, H. L., Wild, O., and Pyle, J. A.: Impact of perturbations to nitrogen oxide emissions from global aviation, J. Geophys. Res., 113, D11305, doi:10.1029/2007JD009140, 2008.

Lacis, A. A., Wuebbles, D. J., and Logan, J. A.: Radiative forcing of climate by changes in the vertical distribution of ozone. J. Geophys. Res., 95, 9971-9981, doi:10.1029/JD095iD07p09971, 1990.

Lee, D. S., Owen, B., Graham, A., Fichter, C., Lim, L. L., and Dimitriu, D.: Allocation of International Aviation Emissions from Scheduled Air Traffic - Present Day and Historical (Report 2 of 3), Manchester Metropolitan University, Centre for Air Transport and the Environment, Manchester, UK, 2005.

Lee, D. S., Fahey, D. W., Forster, P. M., Newton, P. J., Wit, R. C. N., Lim, L. L., Owen, B., and Sausen, R.: Aviation and global climate change in the 21 st century, Atmos. Environ., 43, 17511766, doi:10.1016/j.atmosenv.2009.04.024, 2009.

Macintosh, A. and Wallace, L.: International aviation emissions to 2025: Can emissions be stabilized without restricting demand?, Energy Policy, 37, 264-273, 2009.

Mortlock, A. and Alstyne, R. V.: Military, Charter, Unreported Domestic Traffic and General Aviation: 1976, 1984, 1992, and 2015 Emission Scenarios, NASA CR-1998-207639, available at: http://ntrs.nasa.gov/archive/nasa/casi.ntrs.nasa.gov/ 19980047346_1998120131.pdf, 1998.

Naiman, A. D., Lele, S. K., Wilkerson, J. T., and Jacobson, M. Z.: Parameterization of subgrid plume dilution for use in large-scale atmospheric simulations, Atmos. Chem. Phys., 10, 2551-2560, doi:10.5194/acp-10-2551-2010, 2010.

Owen, B., Lee, D. S., and Lim, L.: Flying into the Future: Aviation Emissions Scenarios to 2050, Environ. Sci. Technol., 44, 22552260, doi:10.1021/es902530z, 2010.

Roof, C., Hansen, A., Fleming, G. G., Thrasher, T., Nguyen, A., Hall, C., Dinges, E., Bea, R., Grandi, F., Kim, B. Y., Usdrowski, S., and Hollingsworth, P.: Aviation Environmental Design Tool (AEDT) System Architecture AEDT-AD-01, 2007.

Schumann, U. and Huntrieser, H.: The global lightning-induced nitrogen oxides source, Atmos. Chem. Phys., 7, 3823-3907, doi:10.5194/acp-7-3823-2007, 2007.

Senzig, D. A., Flemming, G. G., and Iovinelli, R. J.: Modeling of Terminal-Area Airplane Fuel Consumption, J. Aircraft, 46, 
1089-1093, 2009.

Skeie, R. B., Fuglestvedt, J., Berntsen, T., Lund, M. T., Myhre, G., and Rypdal, K.: Global temperature change from the transport sectors: Historical development and future scenarios, Atmos. Environ., 43, 6260-6270, 2009.

Sutkus Jr., D. J., Baughcum, S. L., and DuBois, D. P.: Scheduled Civil Aircract Emission Inventories for 1999: Database Development and Analysis, NASA-CR-2001-211216, 2001.

Thompson, A. M., Friedl, R. R., and Wesoky, H. L. (Eds.): Atmospheric e?ects of aviation. First Report of the Subsonic, NASA Reference Publication 1385, 1996.

Volpe: Volpe National Transportation Systems Center/US DOT, Enhanced Traffic Management System (ETMS), Functional Description, Version 7.6VNTSC-DTS56-TMS-002, 2003.
Waitz, I. A., Lukachko, S. P., and Lee, J. J.: Military Aviation and the Environment: Historical Trends and Comparison to Civil Aviation, J. Aircraft, 42, 329-339, 2005.

Whitt, D., Jacobson, M., Wilkerson, J., Naiman, A., and Lele, S.: Vertical mixing of commercial aviation emissions from cruise altitude to the surface, J. Geophys. Res., 116, D14109, doi:10.1029/2010JD015532, 2011.

Wilkerson, J. T., Jacobson, M. Z., Malwitz, A., Balasubramanian, S., Wayson, R., Fleming, G., Naiman, A. D., and Lele, S. K.: Analysis of emission data from global commercial aviation: 2004 and 2006, Atmos. Chem. Phys., 10, 6391-6408, doi:10.5194/acp-10-6391-2010, 2010. 